\title{
"Optimal investment decision making on the model of production enterprise with limited resources"
}

Tetiana Ivanenko (D https://orcid.org/0000-0001-7580-8483

R http://www.researcherid.com/rid/J-1197-2017

AUTHORS

Viktor Hrushko (D https://orcid.org/0000-0001-6963-9847

Anatolii Frantsuz (D) https://orcid.org/0000-0003-2861-1252

Tetiana Ivanenko, Viktor Hrushko and Anatolii Frantsuz (2018). Optimal

ARTICLE INFO investment decision making on the model of production enterprise with limited resources. Investment Management and Financial Innovations, 15(4), 61-68. doi:10.21511/imfi.15(4).2018.05

DOI http://dx.doi.org/10.21511/imfi.15(4).2018.05

RELEASED ON Tuesday, 23 October 2018

RECEIVED ON

Friday, 31 August 2018

ACCEPTED ON

Thursday, 04 October 2018

\section{(c) EY}

LICENSE

This work is licensed under a Creative Commons Attribution 4.0 International License

JOURNAL "Investment Management and Financial Innovations"

ISSN PRINT $1810-4967$

ISSN ONLINE $1812-9358$

PUBLISHER

LLC "Consulting Publishing Company "Business Perspectives"

FOUNDER LLC "Consulting Publishing Company "Business Perspectives"

NUMBER OF REFERENCES

17
NUMBER OF FIGURES

0
NUMBER OF TABLES

6

(C) The author(s) 2022. This publication is an open access article. 


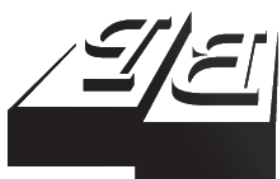

BUSINESS PERSPECTIVES

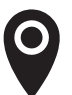

LLC "CPC "Business Perspectives" Hryhorii Skovoroda lane, 10, Sumy, 40022, Ukraine

www.businessperspectives.org

Received on: $31^{\text {st }}$ of August, 2018 Accepted on: $4^{\text {th }}$ of October, 2018

(c) Tetiana Ivanenko, Viktor Hrushko, Anatolii Frantsuz, 2018

Tetiana Ivanenko, Ph.D. in Technical Sciences, Associate Professor, National Technical University of Ukraine "Igor Sikorsky Kyiv Polytechnic Institute", Ukraine.

Viktor Hrushko, Doctor of Economics, Professor, KROK University, Ukraine.

Anatolii Frantsuz, Doctor of Law, Professor, KROK University, Ukraine.

\section{() (i)}

This is an Open Access article, distributed under the terms of the Creative Commons Attribution 4.0 International license, which permits unrestricted re-use, distribution, and reproduction in any medium, provided the original work is properly cited.

\section{OPTIMAL INVESTMENT DECISION MAKING ON THE MODEL OF PRODUCTION ENTERPRISE WITH LIMITED RESOURCES}

\begin{abstract}
Investments are among the most important factors of national economic growth. Selection of optimal investment project is the first priority for any enterprise with limited financial resources. This study is dedicated to a choice among mutually exclusive projects, which are impossible to complete partially, so, one project must be chosen and all others must be rejected. An investor must find among all possible projects the one that allows to better achieve all investor's aims. A mathematical model of multi-purpose multi-criteria investor decision making is proposed for investment project selection problem. Efficiency and riskiness of studied projects are evaluated using such indicators as profit, rate of return, payback period, marginal cost of capital, also taking into account subjective characteristics, namely the investor's attitude towards financial risks, importance assessment of decision making criteria, etc. Decision making assessment methods for the situations of risk and uncertainty are applied to resolve the problem of optimal project selection, such as Wald's pessimistic criterion, maximax optimistic criterion, as well as Hurwicz's, Laplace's, BayesLaplace, Hodges-Lehmann criteria, and Savage's minimax risk criterion. Calculations carried out and results obtained indicate that the best investment project chosen that way will provide the highest absolute profit, despite certain disadvantages such as lower rate of return, longer payback period and higher risk than other projects.
\end{abstract}

\section{Keywords}

MCDM, investor strategies, decision matrix, project selection

\section{JEL Classification D81, G11, H43, O22}

\section{INTRODUCTION}

Investment activity of enterprises is always connected with the problem of limited investment resources. According to statistics, the main source of investments in Ukraine is own funds of enterprises. Rational usage of such funds is a key task. An investor usually can't foresee all possible investment options, but also needs to make decisions, choosing the best strategy to achieve his own goals. In the multi-purpose decision making, a number of goals must be achieved by the selected investment option in the maximum possible degree, measured by several criteria.

The task of making a multi-purpose project selection is to identify and simultaneously optimize several parameters that affect each goal. Such parameters are often not only interrelated, but also controversial. This means that achieving the investor's best values for all parameters is not possible at the same time, because improving one of them leads to a deterioration of the other. Thus, the investor has to make a nonobvious solution, the expediency, and optimality of which must be confirmed by certain calculations. In order to make settlements, the investor, first of all, should formulate the initial conditions of the task, which consists in determining the objectives of decision making and criteria for assessing the degree of achievement of each goal, the possible investor strategies and the state of the economic environment. 


\section{LITERATURE REVIEW}

Various applications of multi-criteria decision making methods in economic studies are described in the article of Mardani et al. (2015), giving an analysis of 393 scientific publications in peer-reviewed journals for the period 20002014. These publications were categorized based on methods of multi-criteria decision making (MCDM), applications, journals etc. Methods of MCDM are classified as discrete and continuous by the fields of application: energy, environmental and sustainability, supply chain management, material, quality management, GIS, construction and project management, safety and risk management, manufacturing systems, information technology management, operation research and soft computing, strategic management, knowledge management, production management, tourism management, and other fields. Metzger and Fehr (2017) conducted a survey of investors concerning attitude toward financial risks and revealed the impact of legal regulations and scientific criteria on investors' behavior. MacNeil (2012) suggests that legal risks must be taken into consideration among other investment risks and also emphasizes the need for regulation of investment to decrease any risks. Pangsri (2015) combines MCDM with Delphi method, AHP, and TOPSIS to analyze decision making in construction enterprise, including expert evaluation of selective criteria.

Problems of optimal decision making in conditions of uncertainty and risk are studied by Vitlinskyi et al. (2002), Kihel (1999). Buz'ko (2014) investigated theoretical approaches to the definition of an investment decision and the conditions for its use in the strategic management of production enterprises. Hlibchuk (2012) analyzes the degree of risk in implementing a long-term investment project and the main principles of the enterprise's investment decision making. Hrydzhuk (2011) examined investment decision making in conditions of multi-criteria uncertainty using statistical methods. Methods of evaluation and key criteria for making investment decisions are considered by Yashkina (2010). Features of making investment decisions are researched by Peresada et al. (2003), Honcharov (2002, 2009). Risk management in entrepreneurial activity is analyzed in the book of Shehda and Holovanenko (2008).
However, the problem of multi-purpose and multi-criteria optimization in choosing one of several alternative investment projects in a context of limited capital and other resources, as well as personal attitudes of a decision maker, isn't sufficiently examined yet.

\section{METHODS}

\subsection{Problem}

The investment process in Ukraine in the last three years shows a moderate recovery. Capital investment in the period 2015-2017 is characterized by the indicators given in Table 1 .

Table 1. Dynamics of capital investments into the Ukrainian economy in the period 2015-2017

\begin{tabular}{l|c:c:c} 
& \multicolumn{3}{c}{ Source: State Statistics Service of Ukraine. } \\
\hline \multicolumn{1}{c}{ Indicator } & $\mathbf{2 0 1 5}$ & $\mathbf{2 0 1 6}$ & $\mathbf{2 0 1 7}$ \\
\hline $\begin{array}{l}\text { Capital investments, UAH } \\
\text { million }\end{array}$ & 273,116 & 359,216 & 412,813 \\
\hdashline Annual increase, \% & - & +31.5 & +14.9 \\
\hdashline Capital investments, USD million & 12,505 & 14,059 & 15,519 \\
\hdashline Annual increase, \% & - & +12.4 & +10.4 \\
\hdashline $\begin{array}{l}\text { Capital investments in tangible } \\
\text { assets, \% }\end{array}$ & 93.3 & 96.7 & 96.3 \\
\hdashline $\begin{array}{l}\text { Capital investments of own } \\
\text { funds, \% }\end{array}$ & 67.5 & 69.3 & 69.9 \\
\hline
\end{tabular}

The data given in Table 1 show a significant increase in the volume of capital investments in the national currency, for example, in 2016, by almost a third compared with 2015. However, it would be more correct to compare these indicators in a stable currency, as during this period the devaluation of the hryvnia continued. An annual increase in investments calculated in US dollars was $10-12 \%$. The vast majority of capital investments consisted of investments in tangible assets: buildings, structures, equipment, its acquisition, modernization, and major repairs. Own funds of enterprises remain the main source of investment with the share of almost $70 \%$. Foreign direct investments and other sources don't exceed $5-10 \%$ of each, namely budgets of different levels, bank loans, and domestic investments. Let's consider the task of making a decision on choosing an investment project for the production enterprise to investits own funds in capital assets.

Investment projectis implemented on production enterprise, the activity of which characterf 
ized as follows. The enterprise operates in the food industry exclusively on the domestic market. The last two years of the enterprise's activity have shown that its products are in demand, and there is a possibility to increase sales volumes by increasing the volume of existing production, as well as by expanding the range of products, as well as improving its quality. However, the investment opportunities of the company are limited and an entrepreneur can realize only one project. So, the way of further development of the enterprise must be chosen from the following options:

1) to establish a production plant in the region $A$ with a promising market for products;

2) to establish a production plant in the region $B$ with a significant resource of cheap labor;

3) to expand existing production;

4) to modernize existing production for the imm provement of products quality.

Also, possible states of the economic environment must be taken into account as significant factors of financial outcome of an enterprise's economic activity. Possible states of the economic environi ment are described as follows:

1) unfavorable (involves an increase in the rate of inflation, reducing the purchasing power of the population, increasing costs of the enterprise and reducing its profits);

2) neutral (characterized by a stable situation in the market);

3) favorable (it involves lowering the rate of inflation, further growth of demand for products of the enterprise, increase of its profits).

\subsection{Mathematical model}

To formulate in mathematical terms the problem of multi-purpose multi-criteria investor decision making, let's introduce the system of three sets:

a functional of evaluation $F: F=\left(F_{1}, F_{2}, \ldots, F_{n}\right)$, where $n$ - the number of criteria for assessing the problem;
1) a set ofinvestorstrategies $S=\left(S_{1}, S_{2}, \ldots, S_{m}\right)$, where $m$ - the number of strategies;

2. a set of states of the economic environment $P=\left(P_{1}, P_{2}, \ldots, P_{l}\right)$, where $l-$ the number of possible states of the environment of the project.

In reality, variable $l$ is continuous, because environment smoothly changes its state. But in order to simplify the model, investor must pick out indicators of discrete environmental states sea quence $P_{t}(t=1, \ldots, l)$.

Let us denote $D$ the set of matrices, each of which corresponds to the investor's partial goal: $D=\left(D^{(1)}, D^{(2)}, \ldots, D^{(k)}\right)$, where $k$ is the number of goals. The elements of these matrices $d_{i j}^{(r)}$ are numbers that characterr ize the degree of achievement by an enterf prise of the partial $r$-th goal in the application of the current strategy of the i-th strategy in $j$-th state of the economic environment $(1 \leq r \leq k, 1 \leq i \leq m, 1 \leq j \leq l)$.

In this sense, the problem of multi-purpose multi-criteria investor decision making is to construct a set of matrices $D$ based on the data sets $F, S$, and $P$ followed by its analyy sis and decision making on choosing an investment strategy to achieve the best result, that is, maximally possible to achieve all the goals simultaneously. It should be noted that the sets $D$ and $F$ are interconnected: $D=f(F)$, or $d_{i j}^{(r)}=f\left(F_{q}\right)(1 \leq q \leq n)$, that is, the degree of achievement of a partial goal depends on which criterion to evaluate it.

Each of the development options is an investor's strategy, so the $S$ set consists of four elements: $S=\left(S_{1}, S_{2}, S_{3}, S_{4}\right)$, respectively. The set of states of the economic environment $P$ consists of three elements: $P=\left(P_{1}, P_{2}, P_{3}\right)$, respectively.

Each project is characterized by different amounts of expected profits, as well as varying degrees of uncertainty, and hence risk. Thus, the investor seeks to achieve two goals: maximizing profits and simultaneously minimizing the risk. Consequently, $D=\left(D^{(1)}, D^{(2)}\right)$, respectively. 
Four criteria are used to assess each project: a net present value of the project $(N P V)$, discounted payback period $(D P P)$, a marginal increase in investment rate of return $(I R R)$ and profitability index $\left(\emptyset^{2}\right)$. Therefore, the evaluation function $F$ is $F=\left(F_{N P V}, F_{D P P}, F_{I R R}, F_{P I}\right)$.

The link between the objectives and criteria for evaluating projects of this task is as follows: $N P V$ determines project outcome in a pei riod of time in absolute units of measurement (thousands UAH, i.e. Ukrainian hryvnia). Therefore, this criterion evaluates the extent to which goal of maximizing profits $D^{(1)}$ is achieved. The criterion of the profitability index of PI characterizes the efficiency of the enterprise since it shows the amount of profit received for each invested monetary unit. PI is a relative dimensionless value and also gives an estimate of the extent to which the goal $D^{(1)}$ is attained. Both criteria are important, because they represent different information about the project: the high value of $N P V$ doesn't always mean high efficiency and can only be achieved at the expense of a large-scale enterprise. IRR criterion indicates the maximum possible value of the invested capital, exceeding which would lead to a lossy project. Therefore, the greater the cost of capital decrease under the critical limit of the IRR, the more secure the state of the enterprise. Based on this, the project risk (degree of achievement of goal $D^{(2)}$ ) can be characterized by $I R R$, which is relative and is measured as a percentage. The criterion of discounted payback period $D P P$ determines the term of return of invested funds and is measured by periods of time (in years, months, days). The faster the investment is paid, the more predictable is the process of project implementation. Therefore, this indicator can also be taken as a criterion for project and goal $D^{(2)}$ risk assessment from another perspective than the $I R R$.

\section{DATA FOR ANALYSIS}

The feasibility study for all projects under different conditions of the economic environment has provided data for analysis and decision making on project selection, as shown in Tables 2-5.
Table 2. NPV - net present value of projects (thousands UAH)

Source: Own calculations

\begin{tabular}{c:c:c:c}
\hline $\mathbf{S}$ & $\mathbf{P}_{\mathbf{1}}$ & $\mathbf{P}_{\mathbf{2}}$ & $\mathbf{P}_{\mathbf{3}}$ \\
\hline $\boldsymbol{S}_{\mathbf{1}}$ & 452 & 513 & 580 \\
\hdashline $\boldsymbol{S}_{\mathbf{2}}$ & 391 & 485 & 552 \\
\hline $\boldsymbol{S}_{\mathbf{3}}$ & 267 & 300 & 389 \\
\hline $\boldsymbol{S}_{\mathbf{4}}$ & 258 & 275 & 311 \\
\hline
\end{tabular}

Table 3. PI - profitability index of projects

Source: Own calculations

\begin{tabular}{|c|c|c|c|}
\hline F & $P_{1}$ & $\boldsymbol{P}_{2}$ & $P_{3}$ \\
\hline$S_{1}$ & 0.95 & 1.25 & 1.38 \\
\hline$S_{2}$ & 1.12 & 1.30 & 1.41 \\
\hline$S_{3}$ & 1.32 & 1.43 & 1.49 \\
\hline$S_{4}$ & 1.30 & 1.47 & 1.52 \\
\hline
\end{tabular}

Table 4. IRR - investment rate of return for projects (\%)

Source: Own calculations

\begin{tabular}{|c|c|c|c|}
\hline 5 & $P_{1}$ & $\boldsymbol{P}_{2}$ & $P_{3}$ \\
\hline$S_{1}$ & 22.05 & 20.15 & 19.20 \\
\hline$S_{2}$ & 22.13 & 19.80 & 19.00 \\
\hline$S_{3}$ & 19.07 & 18.90 & 18.50 \\
\hline$S_{4}$ & 20.11 & 19.30 & 17.83 \\
\hline
\end{tabular}

Table 5. DPP - discounted payback period for projects (years)

Source: Own calculations.

\begin{tabular}{|c|c|c|c|}
\hline $\mathrm{S}$ & $P_{1}$ & $P_{2}$ & $P_{3}$ \\
\hline$S_{1}$ & 5.90 & 5.53 & 4.12 \\
\hline$S_{2}$ & 6.24 & 5.07 & 4.55 \\
\hline$S_{3}$ & 3.83 & 3.21 & 2.75 \\
\hline$S_{4}$ & 3.50 & 3.20 & 2.75 \\
\hline
\end{tabular}

Matrices of partial goals $D=\left(D_{N P V}^{(1)}, D_{P I}^{(1)}, D_{I R R}^{(2)}, D_{D P P}^{(2)}\right)$, according to given data, are:

$$
D_{N P V}^{(1)}=\left(\begin{array}{lll}
452 & 513 & 580 \\
391 & 485 & 552 \\
267 & 300 & 389 \\
258 & 275 & 311
\end{array}\right)
$$




$$
\begin{gathered}
D_{P I}^{(1)}=\left(\begin{array}{lll}
0.95 & 1.25 & 1.38 \\
1.12 & 1.30 & 1.41 \\
1.32 & 1.43 & 1.49 \\
1.30 & 1.47 & 1.52
\end{array}\right) \\
D_{I R R}^{(2)}=\left(\begin{array}{lll}
22.05 & 20.15 & 19.20 \\
22.13 & 19.80 & 19.00 \\
19.07 & 18.19 & 18.50 \\
20.11 & 19.30 & 17.83
\end{array}\right) \\
D_{D P P}^{(2)}=\left(\begin{array}{lll}
5.90 & 5.53 & 4.12 \\
6.24 & 5.07 & 4.55 \\
3.83 & 3.21 & 2.75 \\
3.50 & 3.20 & 2.75
\end{array}\right)
\end{gathered}
$$

For the further calculations, matrix ingredients must be aligned and units of measurement of the matrix elements must be coordinated. An ingredient of a matrix of partial goals is the rule for evaluating the change of matrix elements. If the increase of the elements of the matrix is estimated by the investor as a positive trend, the matrix has a positive constituent, otherwise, it is negative. In the problem under consideration, matrices $D_{N P V}^{(1)}$ and $D_{P I}^{(1)}$ have a positive cone stituent, and the matrices $D_{I R R}^{(2)}$ and $D_{D P P}^{(2)}$ have a negative constituent. Also, it is necessary to coordinate the units of measurement of the matrix elements to ensure their further comparability. To do this, we need to normalize the matrices, which consists in transforming the elements of the matrix $D$ in accordance with a certain rule and obtaining a new, normalized matrix $\widetilde{D}$, whose elements are relative values, their values are within $[0 ; 1]$. There are many different methods of normalizing the matrices, some of which lead to a change in the constituent, and some are not. Therefore, we apply to the matrices $D_{N P V}^{(1)}$ i $D_{P I}^{(1)}$ relative normalization method, which does not change the constituent. This method is realized by the formula (1):

$$
\tilde{d}_{i j}^{(r)}=\frac{d_{i j}^{(r)}}{\max _{1 \leq i \leq m} d_{i j}^{(r)}} .
$$

To the matrices $D_{I R R}^{(2)}$ and $D_{D P P}^{(2)}$ we apply the ree placement of the matrix elements to the inverses by the formula (2):

$$
\tilde{d}_{i j}^{(r)}=\frac{1}{d_{i j}^{(r)}} .
$$

Such a normalization will change the ingredient to the opposite. After the transformations, we get:

$$
\begin{gathered}
\widetilde{D}_{N P V}^{(1)}=\left(\begin{array}{lll}
1.000 & 1.000 & 1.000 \\
0.865 & 0.945 & 0.952 \\
0.591 & 0.585 & 0.671 \\
0.571 & 0.536 & 0.536
\end{array}\right) \\
\widetilde{D}_{P I}^{(1)}=\left(\begin{array}{lll}
0.720 & 0.850 & 0.908 \\
0.848 & 0.884 & 0.928 \\
1.000 & 0.973 & 0.980 \\
0.985 & 1.000 & 1.000
\end{array}\right) \\
\widetilde{D}_{I R R}^{(2)}=\left(\begin{array}{lll}
0.045 & 0.050 & 0.052 \\
0.045 & 0.051 & 0.053 \\
0.052 & 0.053 & 0.054 \\
0.050 & 0.052 & 0.056
\end{array}\right) \\
\widetilde{D}_{D P P}^{(2)}=\left(\begin{array}{lll}
0.169 & 0.181 & 0.243 \\
0.160 & 0.197 & 0.220 \\
0.261 & 0.312 & 0.364 \\
0.286 & 0.313 & 0.364
\end{array}\right)
\end{gathered}
$$

At the next stage, the priorities of the partial goals should be determined and taken into account. The fact is that notall criteria are equallyimportant for an investor. An entrepreneur may prefer one criterion, consider it more important than others. For this purpose, the investor must determine the vector of weight coefficients $\vec{\alpha}=\left(\alpha^{(1)}, \alpha^{(2)}, \ldots, \alpha^{(k)}\right)$, the elements of which reflect the degree of importance of the relevant criterion. Elements of this vector must meet the following requirements: $0 \leq \alpha^{(r)} \leq 1, \quad \forall 1 \leq r \leq k$ and $\sum^{k} \alpha^{(r)}=1$. Let, in the considered model, the investor consider $N P V$ the most important criterion, the second most important be $D P P$ and the less important be $P I$ and IRR. The vector of weight coefficients has the form: $\vec{\alpha}=(0.4 ; 0.2 ; 0.1 ; 0.3)$. Let's apply the linear method of calculating the priority by the formula (3):

$$
\bar{d}_{i j}^{(r)}=\alpha^{(r)} \cdot d_{i j}^{(r)} .
$$

As a result, a new set of matrices $\bar{D}$ is received with elements weighed so that it reflects the level of significance of each criterion for the investor: 


$$
\begin{aligned}
& \bar{D}_{N P V}^{(1)}=\left(\begin{array}{lll}
0.400 & 0.400 & 0.400 \\
0.346 & 0.378 & 0.381 \\
0.236 & 0.234 & 0.268 \\
0.228 & 0.214 & 0.214
\end{array}\right) \\
& \bar{D}_{I R R}^{(2)}=\left(\begin{array}{lll}
0.005 & 0.005 & 0.005 \\
0.005 & 0.005 & 0.005 \\
0.005 & 0.005 & 0.005 \\
0.005 & 0.005 & 0.006
\end{array}\right) \\
& \bar{D}_{D P P}^{(2)}=\left(\begin{array}{lll}
0.051 & 0.054 & 0.073 \\
0.048 & 0.059 & 0.066 \\
0.078 & 0.093 & 0.109 \\
0.086 & 0.094 & 0.109
\end{array}\right)
\end{aligned}
$$

Let's reduce a set of matrices $\bar{D}$ to a single matrix $D^{*}$ by the method of total efficiency using the formula (4):

$$
d^{*}=\sum_{r=1}^{k} \bar{d}_{i j}^{(r)}
$$

After the final calculations, a reduced matrix is:

$$
D^{*}=\left(\begin{array}{lll}
0.5993 & 0.6293 & 0.6596 \\
0.5683 & 0.6193 & 0.6374 \\
0.5199 & 0.5272 & 0.5788 \\
0.5160 & 0.5134 & 0.5292
\end{array}\right) \text {. }
$$

\section{RESULTS}

The optimal investment strategy must be chosen according to the matrix $D^{*}$. The results of the calculations are given in Table 6 .

Let's evaluate the risk of each project by the Savage criterion, considering as the risk a value of unearned profit in the case of choosing a nonoptimal strategy. According to the Savage criterion, it is minimal element between maximum elements chosen in each line of the matrix of diversion, denoted here as $\delta_{i j}$ :

$$
\delta_{i j}=\left(\begin{array}{lll}
0.0000 & 0.0000 & 0.0000 \\
0.0310 & 0.0100 & 0.0222 \\
0.0794 & 0.1021 & 0.0808 \\
0.0833 & 0.1159 & 0.1304
\end{array}\right) .
$$

So, the biggest losses in applying each strategy:

$$
\max _{1 \leq j \leq l} \delta_{i j}=\left(\begin{array}{l}
0.0000 \\
0.0310 \\
0.1021 \\
0.1304
\end{array}\right) \quad \min _{1 \leq i \leq m} \max _{1 \leq i \leq 1} \delta_{i j}=0.0000 .
$$

As a result, the first strategy is also characterized by the minimal risk in the worst conditions.

Table 6. Estimation of investor strategies and recommendations for choosing alternatives

Source: Own calculations.

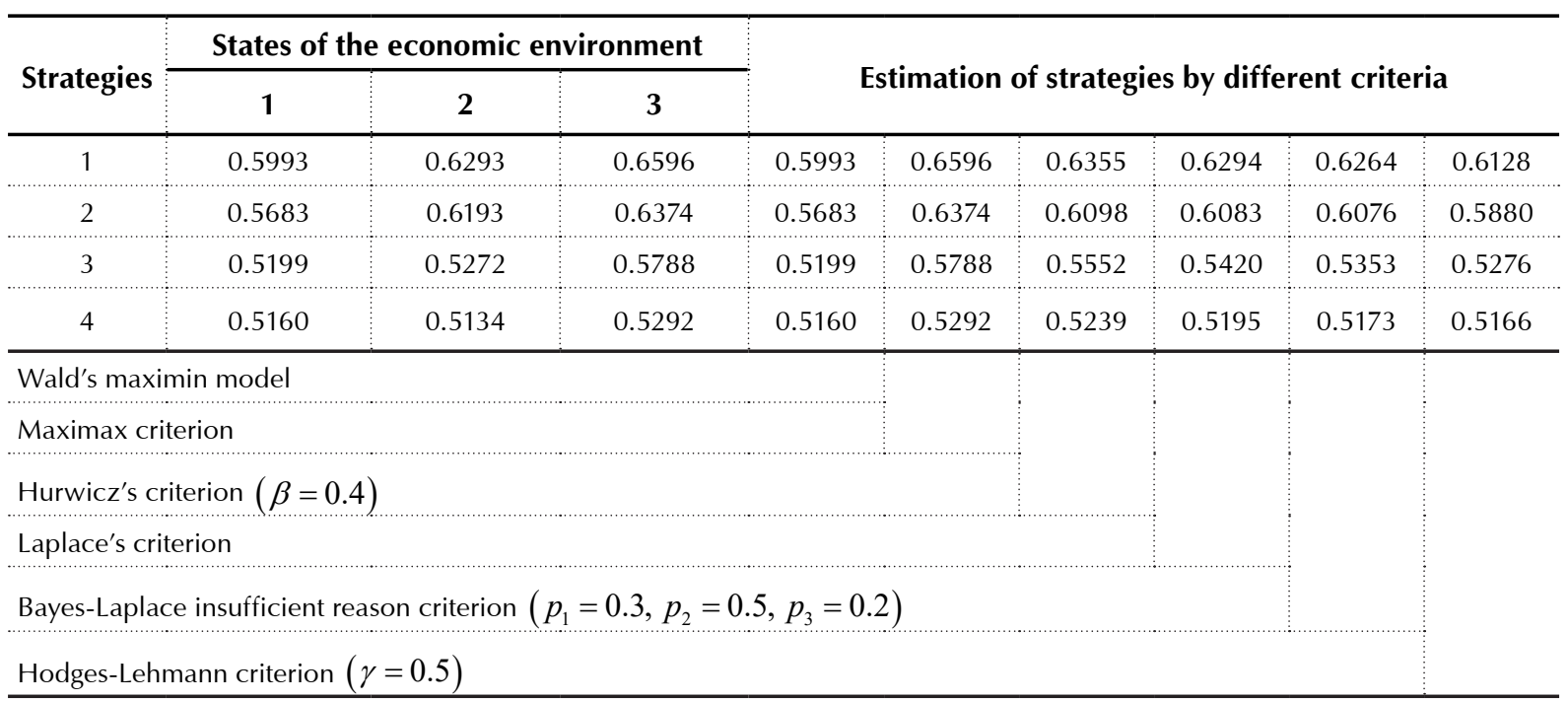




\section{DISCUSSION}

In view of performed calculations, the next recommendations may be given to the investor. All criteria indicate that the optimal solution under these conditions is the choice of the first strategy, that is, the investor should establish a production plant in the region A with a promising market for products. Although this project will bring the highest absolute profit in comparison with others, it has less efficiency, the highest payback period and the highest marginal cost of capital. To a large extent, a concrete choice depends on the personal qualities of the investor, like risk attitude, propensity to optimism or pessimism, and investor's mood, influenced by market mood, which may be panic or frivolous. Gambling or scared investor can underestimate scientific assessment and choose extremely risky projects to invest, harmful to partners and society, and the total weight of toxic risks can cause the economic crisis; to prevent such danger, legislation is needed to minimize investment risks, encourage insurance of investments. Also, in the analyzed example, all of the six criteria gave the same result, but other examples can be proposed, where these criteria give contradictory results. Different types of investors prefer different criteria in such case. Cautious investor prefers the Wald's criterion for a guaranteed result. Optimistic investor chooses the maximax criterion in hope for the best result. Weighted investor prefers Hurwitz's criterion, defining the indicator $\beta$ according to pessimistic expectations. When applying the Laplace criterion, the investor believes that all the states of the economic environment are equally possible; instead, the Bayes-Laplace criterion uses a certain probabilistic distribution of environmental states $\left(p_{1}, p_{2}, p_{3}\right)$, and the Hodges-Lehman criterion takes into account the degree of confidence in this probabilistic distribution $(\gamma)$. In any case, one criterion must be chosen to assess alternative strategies and give recommendations.

\section{CONCLUSION}

Studying the application of optimal decision making theory in investment management, we considered an investment project selection problem in the case of four available projects, varying on characteristics of efficiency and riskiness. This problem was formalized, a mathematical model was developed for multi-purpose multi-criteria optimization. In result, it is shown that the first project according to its parameters fits the best to all investor's requirements. Of course, it isn't the best by the all parameters: only the profitability of project implementation, measured by net present value (NPV), prevails over the rest of the projects for all the states of the economic environment. But values of discounted payback period (DPP), investment rate of return (IRR) and profitability index (PI) of the first project are inferior to other projects. However, calculations show that the first project is optimal for this investor, because the mathematical model also takes into account personal attitudes, expressed by an investor's priorities. In our model investor preferred the NPV, considering the rest of the indicators less significant, but for another investor optimal choice could be different.

\section{REFERENCES}

1. Buzko, I. R. (2014).

Інвестиційне рішення в стратегічному управлінні виробничих підприємств [Investytsiine rishennia v stratehichnomu upravlinni vyrobnychykh pidpryiemstv]. Ekonomika: realii chasu, 6(16), 224-228. Retrieved from https:// economics.opu.ua/files/archive/2014/No6/224-228.pdf
2. Goncharov, Y. V. (2009). Оценка риска инвестиционного проекта методом имитационного моделирования [Otsenka riska investitsionnogo proekta metodom imitatsionnogo modelirovaniya]. Tekhnicheskiy progress i effektivnost proizvodstva: Vestnik Kharkovskogo gosudarstvennogo politekhnicheskogo unsverssteta. Sbornik nauchnykh trudov, 90, 36-40. Kharkov: KhDPU.

3. Hlibchuk, V. M. (2012). O6грунтування прийняття інвестиційних рішень для підприємств нафтогазової промисловості [Obhruntuvannia pryiniattia investytsiinykh rishen dlia pidpryiemstv naftohazovoi promyslovosti]. Naukovyi visnyk 
IFNTUNH, 1(31). Retrieved from http://nv.nung.edu.ua/index.php/ nv/article/view/108

4. Honcharov, Y. V. (2002). Ризик та прийняття управлінських рімень [Ryzyk ta pryiniattia upravlinskykh rishen] (160 p.). Kharkiv: NTU "KhPI".

5. Hrydzhuk, I. А. (2011). Прийняття інвестиційних рішень в умовах багатокритеріальної невизначеності: теоретичний аспект [Pryiniattia investytsiinykh rishen $\mathrm{v}$ umovakh bahatokryterialnoi nevyznachenosti: teoretychnyi aspekt]. Elektronne naukove fakhove vydannia "Efektyvna ekonomika" Dnipropetrovskyi derzhavnyi ahrarno-ekonomichnyi universytet, 5. Retrieved from http://www.economy.nayka.com. $\mathrm{ua} /$ ?op $=1 \& \mathrm{z}=556$

6. Kihel, V. R. (1999). Математичні методи прийняття рімень $y$ ефбективному підприємництві [Matematychni metody pryiniattia rishen u efektyvnomu pidpryiemnytstvi] (270 p). Kyiv: IEUHP.

7. Kini, R., Raifa, Kh. (1991). Принятие решений при многих критериях: предпочтения и замещения [Prinyatie resheniy pri mnogikh kriteriyakh: predpochteniya y zameshcheniya] (560 p.). Moscow: Mir.

8. MacNeil, I. (2012). An Introduction to the Law on Financial Investment (542 p.). Oxford: Hart Publishing.

9. Mardani, A. et al. (2015). Multiple criteria decision-making techniques and their applications - a review of the literature from 2000 to 2014. Economic ResearchEkonomska Istraživanja, 516-571. https://doi.org/10.1080/133167 7X.2015.1075139

10. Metzger, A., Fehr, R. (2017). Measuring Financial Risk Attitude: How to Apply Both Regulatory and Scientific Criteria to Ensure Suitability. Journal of Behavioral Finance, 221-234. https://doi.org/1 $0.1080 / 15427560.2017 .1376331$

11. Pangsri, P. (2015). Application of the Multi Criteria Decision Making Methods for Project Selection. Universal Journal of Management, 3(1), 15-20. https:// doi.org/10.13189/ujm.2015.030103

12. Peresada, A. A., Kovalenko, Yu. M., Onikiienko, S. V. (2003). Інвестиційний аналіз [Investytsiinyi analiz] (485 p.). Kyiv: KNEU.
13. Shehda, A. V., Holovanenko, M. V. (2008). Ризики в підприємництві: оцінювання та управління [Ryzyky v pidpryiemnytstvi: otsiniuvannia ta upravlinnia] (271 p.). Kyiv: Znannia.

14. State Statistics Service of Ukraine (n.d.). Statistical bulletins "Capital investment in Ukraine" for 2015-2017. Retrieved from http:// www.ukrstat.gov.ua/

15. Vitlinskyi, V. V., Verchenko, P. I., Sihal, A. V., \& Nakonechnyi, Ya. S. (2002). Економічний ризик: ігрові моделі [Ekonomichnyi ryzyk: ihrovi modeli] (446 p.). Kyiv: KNEU.

16. Voloshyn, O. F., \& Maschenko, S. O. (2006). Моделі та методи прийняття рішень [Modeli ta metody pryiniattia rishen] (336 p.) Kyiv: Kyivskyi universytet.

17. Yashkina, N. V. (2010). Прийняття інвестиційних рішень: методи оцінки та основні критерії [Pryiniattia investytsiinykh rishen: metody otsinky ta osnovni kryterii]. Investytsii: praktyka ta dosvid, 10, 6-8. Retrieved from http://www.investplan.com. $\mathrm{ua} /$ ?op $=1 \& \mathrm{z}=580 \& \mathrm{i}=1$ 